\title{
Characteristics and pathogenicity of a novel herpesvirus isolated from adult and subadult white sturgeon Acipenser transmontanus
}

\author{
L. R. Watson, S. C. Yun, J. M. Groff, R. P. Hedrick* \\ Department of Medicine and Epidemiology, School of Veterinary Medicine, University of California, Davis, \\ California 95616, USA
}

\begin{abstract}
A syncytium-inducing viral agent was initially isolated from the ovarian fluid of a domestic white sturgeon Acipenser transmontanus female using the sturgeon spleen cell line WSS-2. Examination of infected cells by transmission electron microscopy revealed ultrastructural characteristics typical of the Herpesviridae. On the basis of differences shown by comparative in vitro growth studies and serological assays, the new adult isolate was tentatively designated WSHV-2 to distinguish it from a previously reported herpesvirus from juvenile white sturgeon, WSHV (WSHV-1). A water-borne transmission trial at 3 virus concentrations was conducted to determine the susceptibility of juvenile sturgeon to the newly isolated virus. At virus doses of $10^{5}$ and $10^{4} \mathrm{TCID}_{50} \mathrm{ml}^{-1}$ cumulative mortality reached $80 \%$ within 6 wk at a water temperature of $17^{\circ} \mathrm{C}$. Virus was reisolated from all mortalıties with concentrations approaching $10^{7} \mathrm{TCID}_{50} \mathrm{~g}^{-1}$ in cutaneous epithelial tissues where severe hyperplastic lesions were observed. Challenge with $10^{3} \mathrm{TCID}_{50} \mathrm{ml}^{-1}$ of WSHV-2 falled to induce clinical signs or mortality, although chronic subclinical infections were detected in a majority of survivors $70 \mathrm{~d}$ postchallenge. During our investigations of WSHV-2 from adult sturgeon, a second virus isolation was obtained from ulcerative skin lesions of naturally infected subadult white sturgeon. This virus induced identical cytopathic effects in WSS-2 cells to that caused by the adult isolate from ovarian fluid. Serum anti-WSHV-2 neutralizing activity was detected in subadults with skin lesions and among fish recovering from these lesions. Serum from naturally-infected juveniles and serum from adults hyperimmunized with the WSHV-2 from the ovarian fluid were used to compare the adult and subadult viruses. The 2 agents were neutralized with these 2 sera which conversely failed to neutralize WSHV- 1 at the lowest dilution tested. Our studies demonstrate that at least 2 pathogenic herpesviruses are found among white sturgeon. The newly recognized WSHV-2 can cause both acute and chronic infections and possibly a latent carrier state in white sturgeon. WSHV-2 is the fourth virus to be observed as a cause of juvenile mortality among intensively reared white sturgeon populations.
\end{abstract}

KEY WORDS: Herpesvirus Skin lesion S Sturgeon

\section{INTRODUCTION}

The sensitivity of sturgeons to habitat alterations and fishery exploitation is greater than that of other anadromous species and is an important factor contributing to recent declines in feral populations in the Pacific Northwest since the late 1800s (Doroshov 1985, Conte 1988, PSMFC 1992). The dilemma caused by diminishing natural recruitment, combined with rising

\footnotetext{
- Addressee for correspondence
}

commercial and recreational demand (Hempel 1993), has fostered the recent emergence of the sturgeon aquaculture industry. Commercial sturgeon growers are becoming increasingly aware of acute and chronic diseases which can impact production. Moreover, from a fisheries resource perspective, there are potential threats to native sturgeon populations from infectious agents associated with hatchery outplants (Carey 1983, Goede 1986, PSMFC 1992).

The most serious white sturgeon viral pathogens are a putative iridovirus (WSIV), which has been associated with up to $95 \%$ mortality of farm-reared fry 
(Hedrick et al. 1990), and a herpesvirus, WSHV recently identified as the etiologic agent responsible for serious losses of hatchery fry and fingerlings (Hedrick et al. 1991a). This report describes a second herpesvirus agent first detected in ovarian fluids of a healthy, reproductively mature captive white sturgeon during routine broodstock sampling. The adult virus, tentatively designated WSHV-2 (Type 2) to distinguish it from WSHV-1 (Type 1), displays different cytopathic effects (CPE) and growth optima in sturgeon cell lines compared to WSHV-1. Water-borne transmission was attempted to determine the susceptibility of juvenile sturgeon to WSHV-2 and to identify host target tissues as compared to those reported for WSHV-1.

During the course of our studies on WSHV-2, a virus which dispiayed WSHV-2-like CPE was isolated from dermal lesions of subadult white sturgeon. Attempts to produce polyclonal rabbit antibodies to either of the WSHV-2 isolates or to WSHV-1 were unsuccessful. However, the adult and subadult viruses (WSHV-2) were compared to WSHV-1 using sera with neutralizing activity to WSHV-2 from hyperimmunized adults and actively infected subadults. These studies demonstrated that at least 2 distinct herpesviruses (WSHV-1 and 2) are found among captive white sturgeon populations.

\section{MATERIALS AND METHODS}

Broodstock. A limited sampling program was initiated in 1991 at the University of California, Davis (UCD) to assess the incidence and prevalence of infectious agents in wild and captive white sturgeon populations intended for use as broodstock for intensive hatchery operations in the Sacramento and San Joaquin River basins. In 1991 and 1992, a total of 40 fish were examined of which 13 were wild-caught females, 7 captive females and 20 captive males. The weight range for adult sturgeon was 34 to $75 \mathrm{~kg}$ and the age of captive broodstock was 8 to $10 \mathrm{yr}$, whereas wild-caught females were estimated at $>15$ yr of age. Adult sturgeon that were sampled from March through May included gravid females from the commercial fishery in the Sacramento River and captive adults from 4 commercial farms and the experimental hatchery at UCD

Virus screening. Tissues (ovaries, gill, skin and blood) and fluids (ovarian and seminal) were obtained from live fish during spawning operations. Gonads were screened for virus by collecting a $1 \mathrm{~g}$ sample of ovarian tissue and $20 \mathrm{ml}$ of ovarian fluid from females or milt from males. Tissue and fluid samples were transported on ice to UCD and processed by a modification of the standard procedures described by Amos
(1985). Ovarian tissues were diluted 1:2 in Earle's Minimum Essential Medium (MEM) containing antibiotics (200 IU ml $\mathrm{ml}^{-1}$ penicillin, $200 \mu \mathrm{g} \mathrm{ml}^{-1}$ streptomycin) and extracted with a Stomacher 80 Lab Blender prior to removal of cellular debris by centrifugation at $1300 \times g$ for $10 \mathrm{~min}$. After $24 \mathrm{~h}$ at $10^{\circ} \mathrm{C}$ the supernatant was diluted to 1:25 in MEM supplemented with $2 \mathrm{mM} \mathrm{L-}$ glutamine, $2 \%$ fetal bovine serum and $15 \mathrm{mM}$ HEPES (N-2-hydroxyethylpiperazine-N-2-ethanesulfonic acid) buffer (MEM-2-H) and an $0.1 \mathrm{ml}$ aliquot of the extract was inoculated onto confluent sturgeon spleen (WSS-2) and skin (WSSK-1) cells (Hedrick et al. 1991) in triplicate wells of 24 -well titration plates (Nunclon). The samples were incubated at $15^{\circ} \mathrm{C}$ for $1 \mathrm{~h}$, then each well received $1 \mathrm{mI}$ MEM-2-H. Ovarian fluids and milt were centrifuged to remove cellular debris, diluted and inoculated as described above.

Virus isolation and propagation. Plates with the broodstock tissue and fluid samples were incubated at $15^{\circ} \mathrm{C}$ and examined daily by phase contrast microscopy for evidence of cytopathic effects (CPE) for a minimum of $8 \mathrm{wk}$. Supernatants were blind-passaged and observed for an additional $8 \mathrm{wk}$. Supernatants from wells exhibiting CPE were inoculated on approximately $10^{6.7}$ confluent WSS-2 cells in a $25 \mathrm{~cm}^{2}$ flask at $15^{\circ} \mathrm{C}$, and after 12 to $14 \mathrm{~d}$ the supernatant was titrated in serial 10 -fold dilutions using 8 replicate wells of a 96-well plate containing monolayers of WSS-2 cells. The newly isolated virus from adult ovarian fluids, hereafter referred to as 'WSHV-2a', was quantified by calculation of the $50 \%$ tissue culture infective dose or $\mathrm{TCID}_{50} \mathrm{ml}^{-1}$ using the method of Reed \& Muench (1938).

Additional clinical isolates were obtained in 1993 from farm-reared 2 -yr-old subadult fish $(0.75 \mathrm{~kg})$ submitted for routine diagnostic examination to determine the cause of recurrent morbidity and mortality associated with multifocal erosions of the dermis. The outbreak was coincidental with recent handling in the course of normal hatchery operations. Virus was isolated, at concentrations as high as $10^{6.9} \mathrm{TCID}_{50} \mathrm{~g}^{-1}$, from skin specimens by the same procedures used above for ovarian tissues. The appearance of WSHV-2like CPE resulted in its designation as the 'WSHV-2b' isolate.

Electron microscopy. Virion ultrastructure of WSHV-2a was examined by electron microscopy of WSSK-1 cells infected at a multiplicity of infection $(\mathrm{MOI})=0.1 \mathrm{TCID}_{50}$ cell $^{-1}$ after 8 d at $20^{\circ} \mathrm{C}$. The cells were fixed as a monolayer in $2.5 \%$ glutaraldehyde in $0.06 \mathrm{M}$ cacodylate buffer for $4 \mathrm{~h}$ at $4^{\circ} \mathrm{C}$. Fixed cells were then scraped from the flask, rinsed in buffer and postfixed in $1 \%$ aqueous $\mathrm{OsO}_{4}$, dehydrated through a graded ethanol series and embedded in epoxy resin. Thin sections were stained with $4 \%$ uranyl acetate and 
lead citrate prior to examination with a Phillips 400 electron microscope at $80 \mathrm{kV}$

In vitro host cell range. Replication of the virus was examined in 5 established cell lines from channel catfish ovary (CCO; Bowser \& Plumb 1980), chinook salmon embryo (CHSE-214; Lannan et al. 1984), rainbow trout gonad (RTG-2; Wolf \& Quimby 1962). Epithelioma papulosum cyprini (EPC; Fijan et al. 1983) and fathead minnow (FHM; Gravell \& Malsberger 1965). In addition, 4 established (>40 passages) cell lines from white sturgeon spleen (WSS-2) and skin (WSSK-1) (Hedrick et al. 1991b), liver (WSLV) and gonad (WSGO) (unpubl. data) were tested. The cells were grown to $90 \%$ confluence in $25 \mathrm{~cm}^{2}$ flasks and inoculated with a stock from the 14 th passage of the WSHV-2 at an approximate $\mathrm{MOI}=0.1$ and examined for a minimum of $4 \mathrm{wk}$.

In a subsequent experiment, growth of the WSHV-1 and WSHV-2a in these 4 sturgeon cell lines was evaluated. WSHV-1 and WSHV-2a were grown in WSSK-1 cells, stored at $-70^{\circ} \mathrm{C}$ and titered after thawing. Three replicate $25 \mathrm{~cm}^{2}$ flasks of each cell line were prepared. The cells from 1 flask were counted following treatment with trypsin/EDTA. The 2 remaining flasks of each cell line were inoculated with either WSHV-1 or WSHV-2a at a $\mathrm{MOI}=0.05\left(\mathrm{TCID}_{50} \mathrm{cell}^{-1}\right)$. The flasks were incubated at $15^{\circ} \mathrm{C}$ for $2 \mathrm{wk}$, after which the supernatant was decanted and any remaining attached cells were scraped and gently disrupted by 10 strokes in a Ten Broek homogenizer For each flask, cell debris was removed from the cell extract by low speed centrifugation, the supernatant and cell extract were combined, serially 10 -fold diluted and titrated by TCID $_{50}$ analyses using WSSK-1 cells.

Light microscopy. Preliminary experiments showed that the best cell line supporting the replication of both WSHV-1 and WSHV-2a was the WSSK-1 Cytomorphological changes induced by WSHV-1 and WSHV2a were therefore compared in WSSK-1 cells by phase contrast microscopic examination of live cultures in $25 \mathrm{~cm}^{2}$ flasks.

Hyperimmunization of white sturgeon with WSHV2a. Ten yearling sturgeon, reared in the Fish Disease Laboratory at UCD in $17^{\circ} \mathrm{C}$ well water and weighing an average of $100 \mathrm{~g}$ each, were injected intraperitoneally with $1 \mathrm{ml}$ of a 1:3 emulsion of semi-purified WSHV-2a as pelleted from the clarified supernatant of infected WSSK-1 cells and Freund's incomplete adjuvant (FIA). The injection dose contained approximately $10^{8.0}$ $\mathrm{TCID}_{50}$ of WSHV-2a and was administered at 1 mo intervals for 3 mo. Fish were bled 2 wk after each boost. The blood was clotted at room temperature, centrifuged and the serum collected and frozen at $-20^{\circ} \mathrm{C}$. Ten control fish were similarly treated following injections with a 1:3 emulsion of MEM-2-H and FIA.
Experimental challenge and fish sampling. The pathogenicity of the adult white sturgeon virus to juvenile sturgeon was studied in a water-borne infection trial. A volume of $120 \mathrm{ml}$ of cell-free supernatant from the 8th passage of WSHV-2a on WSS-2 cells containing $10^{62}$ TCID $_{50} \mathrm{ml}^{-1}$ was diluted $1: 13$ in ambient $\left(17^{\circ} \mathrm{C}\right)$ well water to a total volume of 1.51 (Group A, $10^{5.1}$ $\mathrm{TCID}_{50} \mathrm{ml}^{-1}$ ). Two additional $1.5 \mathrm{l}$ baths were prepared from 10-fold dilutions of the first solution to yield Group $B$ and $C$ challenge baths $\left(10^{41}\right.$ and $10^{3.1} \mathrm{TCID}_{50} \mathrm{ml}^{-1}$, respectively). Three parallel control baths were prepared with MEM-2-H at dilutions of 1:13, 1:130 and 1:1300 in ambient water. Thirty healthy 5 mo old white sturgeon juveniles (1.5 g, $70 \mathrm{~mm}$ in total length) reared in $17^{\circ} \mathrm{C}$ well water were divided into 3 groups of 10 fish, each of which were immersed in one of the challenge baths ( $\mathrm{A}, \mathrm{B}$ or $\mathrm{C}$ ) for $1 \mathrm{~h}$. Twenty-one additional fish were divided into 3 equal groups and treated similarly by immersion in MEM-2-H (Control A, B and C). All groups of fish were then transferred to separate 201 aquaria receiving single-pass $17^{\circ} \mathrm{C}$ well water at a flow rate of $0.51 \mathrm{~min}^{-1}$. It was necessary to remove 1 fish in Group A on the second day post-challenge due to accidental injury. Fish were fed once daily with a commercial trout diet. Clinical signs were monitored twice daily and freshly dead fish were removed and selected tissues were collected for viral infectivity assays (Group A, $n=4$; Group B, $n=5$ ). Portions of several of these dead fish were fixed for histological examination (Group A, n= 1; Group B, n=4). The study was terminated after $70 \mathrm{~d}$ and at this time fish for viral assay and histological examination were randomly collected from the remaining survivors in the challenge Group $\mathrm{C}$ ( $\mathrm{n}=$ 6) and control Groups A, B and C ( $\mathrm{n}=3$ for each group).

Virus isolation. Attempts to recover virus from experimental and control fish were conducted by inoculating WSS-2 cells with the diluted extracts of tissues from freshly dead fish or survivors. Routinely, 6 tissues were collected from each fish for a total of 175 tissues sampled from all groups (Table 1). Portions of the integument (4 barbels; left half of oral siphon/left operculum; distal halves of both pectoral fins) and gills ( 2 or 3 arches) were first removed with flame-sterilized equipment. After collection of external tissues, the skin was disinfected with $70 \%$ ethanol and portions of the esophagus (anterior to pneumatic duct), heart, liver (right anterior lobe), spleen, mid-kidney, and brain were removed, using care to avoid cross-contamination between samples. Excised tissue samples were placed in tared vials containing $1 \mathrm{ml}$ of antibiotic solution (as above) and were then weighed, homogenized and diluted to 1:25 in MEM-2-H. These clarified supernatants were serially 10 -fold diluted (MEM-2-H) for titration on WSS-2 cells in 96-well plates. Virus was quantified as the TCID $50 \mathrm{~g}^{-1}$ wet weight of tissue. 
Table 1 Acipenser transmontanus. Virus recovery from selected tissues of freshly dead fish (Groups A and B) and survivors (Group C) following bath challenge with WSHV-2a

\begin{tabular}{|c|c|c|c|c|c|c|c|c|c|c|}
\hline \multirow[t]{2}{*}{ Test group } & \multicolumn{10}{|c|}{ Tissue group } \\
\hline & $b b^{a}$ & pf & s/o & g & e & $\mathrm{br}$ & $\mathrm{k}$ & h & 1 & $\mathrm{~s}$ \\
\hline \multicolumn{11}{|l|}{ Group $A \& B$} \\
\hline Dead fish ${ }^{b}$ & $9^{c}$ & 13 & 13 & 12 & 13 & 6 & 7 & 8 & 8 & 11 \\
\hline No. virus-positived & 8 & 10 & 10 & 9 & 9 & 3 & 3 & 3 & 3 & 3 \\
\hline$\%$ positive & 88.9 & 76.9 & 76.9 & 75.0 & 69.2 & 50.0 & 42.9 & 37.5 & 37.5 & 27.3 \\
\hline \multicolumn{11}{|l|}{ Group C } \\
\hline Survivors 1 & $--^{9}$ & - & - & 6 & 6 & - & 6 & - & 6 & 6 \\
\hline No. virus-positive & -- & - & - & 4 & 5 & - & 6 & - & 4 & 6 \\
\hline$\%$ positive & - & - & - & 66.7 & 83.3 & - & 100 & - & 66.7 & 100 \\
\hline Controls ${ }^{h}$ & - & 9 & - & 9 & 9 & - & - & 9 & - & 9 \\
\hline No positive & - & 0 & - & 0 & 0 & - & - & 0 & - & 0 \\
\hline $\begin{array}{l}\text { "Tissue groups: bb, b } \\
\text { l, liver; s, spleen } \\
\text { Tissues collected fro } \\
\text { "Total number of tissu } \\
\text { d Total number of posi } \\
\text { e Percentage of sampl } \\
\text { 'Tissues collected fror } \\
\text { Not sampled } \\
\text { 'Tissues collected fro }\end{array}$ & $\begin{array}{l}\text { els; pf, } \\
\text { ead fis } \\
\text { analyz } \\
\text { tissue } \\
\text { hat we } \\
\text { arvivor } \\
\text { n.chall }\end{array}$ & $\begin{array}{l}\text { ositive } \\
\text { WSH } \\
\text { ed con }\end{array}$ & $\begin{array}{l}\text { chall } \\
\text { s at } 70\end{array}$ & $\begin{array}{l}\text { hon/o } \\
\text { e Grou }\end{array}$ & $\begin{array}{l}\text { ulum; } \\
A \text { and }\end{array}$ & $l_{i} e_{1}$ e & hagus; & orain; & idney; & neart; \\
\hline
\end{tabular}

Histopathology. Immediately after samples were obtained for viral isolation, several dead fish were fixed for histological examination to ascertain the extent and type of histopathological changes associated with viral infection. Dissected whole fish were placed in Bouin's fixative for $24 \mathrm{~h}$ and then changed to $70 \%$ ethanol prior to paraffin embedding, processing and staining with hematoxylin and eosin.

Serum neutralization assay. The sera obtained from juveniles of experimental exposures (E-WSHV-2), or subadults with naturally occurring skin lesions ( $N$ Sick) or recovering from lesions ( $N$-Convalescent), and mature adults (Captive-Adult) of unknown exposure history, were assayed for WSHV-2a neutralizing activity. Sera were diluted 1:20 in MEM-0-H and heat-inactivated for $30 \mathrm{~min}$ at $45^{\circ} \mathrm{C}$. Final serum dilutions, prepared by serial 2 -fold dilutions in duplicate wells of a 96-well plate, ranged from 1:40 to $1: 5120$ after the addition of virus. WSHV-2a grown in WSS-2 cells (approximately 50 PFU) was added to each well containing diluted serum. The plates were then incubated at $20^{\circ} \mathrm{C}$ with rocking for $30 \mathrm{~min}$. Duplicate wells of WSSK-1 cells in a 24 -well plate were then inoculated with $0.1 \mathrm{ml}$ of each virus-serum dilution, adsorbed for 1 $\mathrm{h}$ at $15^{\circ} \mathrm{C}$ and overlaid with $0.5 \mathrm{ml}$ MEM-2-H containing $0.75 \%$ methylcellulose. After $4 \mathrm{~d}$ at $20^{\circ} \mathrm{C}$, cells in the plates were fixed and stained with $10 \%$ formalin containing $1 \%$ crystal violet and plaques were counted. The $50 \%$ plaque reduction endpoint was cal- culated on the basis of the mean number of plaques in the duplicate wells compared to a control using pooled serum from 5 normal juveniles. These control fish were from a 1992 cohort reared at our laboratory with no known history or evidence of contact with any of the white sturgeon viruses.

In a second trial to determine the antigenic relatedness of the WSHV-1 and WSHV-2a and b isolates, sera from 2 fish with high neutralizing activity from Groups E-WSHV-2 and N-Convalescent, respectively, were serially 2 -fold diluted and equal volumes were added to virus suspensions containing approximately 100 $\mathrm{TCID}_{50}$ of each isolate. The virus-serum mixtures were incubated for $1 \mathrm{~h}$ at $15^{\circ} \mathrm{C}$ and then inoculated $(6$ replicates per dilution) on WSSK-1 monolayers in 96-well plates. The $50 \%$ serum neutralizing dose ( $N D_{50}$ ) was calculated as the serum dilution at which half of the virus was neutralized compared to a serum-free control.

\section{RESULTS}

\section{Virus isolation and cytopathic effect}

An ovarian fluid sample from a captive female initially induced focal rounding, enhanced refractility, enlargement and detachment of individual WSS-2 cells approximately $4 \mathrm{wk}$ after the primary inoculation. 
Subsequent passages produced consistent and progressive cytopathic effects consisting of swollen, vacuolated and heteromorphic single and fused cells resembling syncytia within 5 to $7 \mathrm{~d}$ after inoculation.

Further studies of WSHV-2 inoculated on to WSSK-1 cells (Fig. 1A) revealed a number of unique cytopathological changes compared to other known sturgeon viruses including the formation of discrete, grape-like clusters of cells adjacent to the infective foci (Fig. 1B). These aggregates detached readily from the substrate and gave rise to plaques under methylcellulose overlays which were not found with WSHV-1. In contrast, WSHV-1 syncytia formed from fusion of neighboring cells into a globoid giant cell in which individual cell boundaries were obscured and the aggregates remained adherent (Fig. 1C).

\section{Virus ultrastructure and development}

Transmission electron microscopy of WSHV2a infected WSSK-1 cells revealed hexagonal capsids surrounding nucleoprotein cores of variable density distributed in the nucleus and throughout the cytoplasm (Fig 2A). Nuclear membranes remained largely intact but other cytopathological changes were evident, including chromatin margination, mitochondrial swelling and fusion or fragmentation of unit membranes between cells.

Intranuclear nucleocapsids measuring $107 \mathrm{~nm}$ in diameter ( $n=57$ ) were morphologically variable and contained cores ranging from granular, fragmentary circles to solid, opaque bars. Nucleocapsid envelopment involved passage of the shell through the inner nuclear lamina into the perinuclear space (Fig. 2B). The mean diameter of these enveloped virions was $177 \mathrm{~nm}$ ( $\mathrm{n}=20$, Fig. 2C) and the envelope was composed of a fine dense matrix interspersed with low density granules. A fibrillar fringe on the periphery of the particles, external to the envelope, was composed of peplomers measuring approximately $10 \mathrm{~nm}$. A low density tegument was observed between the outer electron-opaque envelope and the capsid shell.

\section{Host cell range}

A MOI of approximately 0.1 of WSHV-1 or WSHV-2a produced CPE in all 4 sturgeon cell

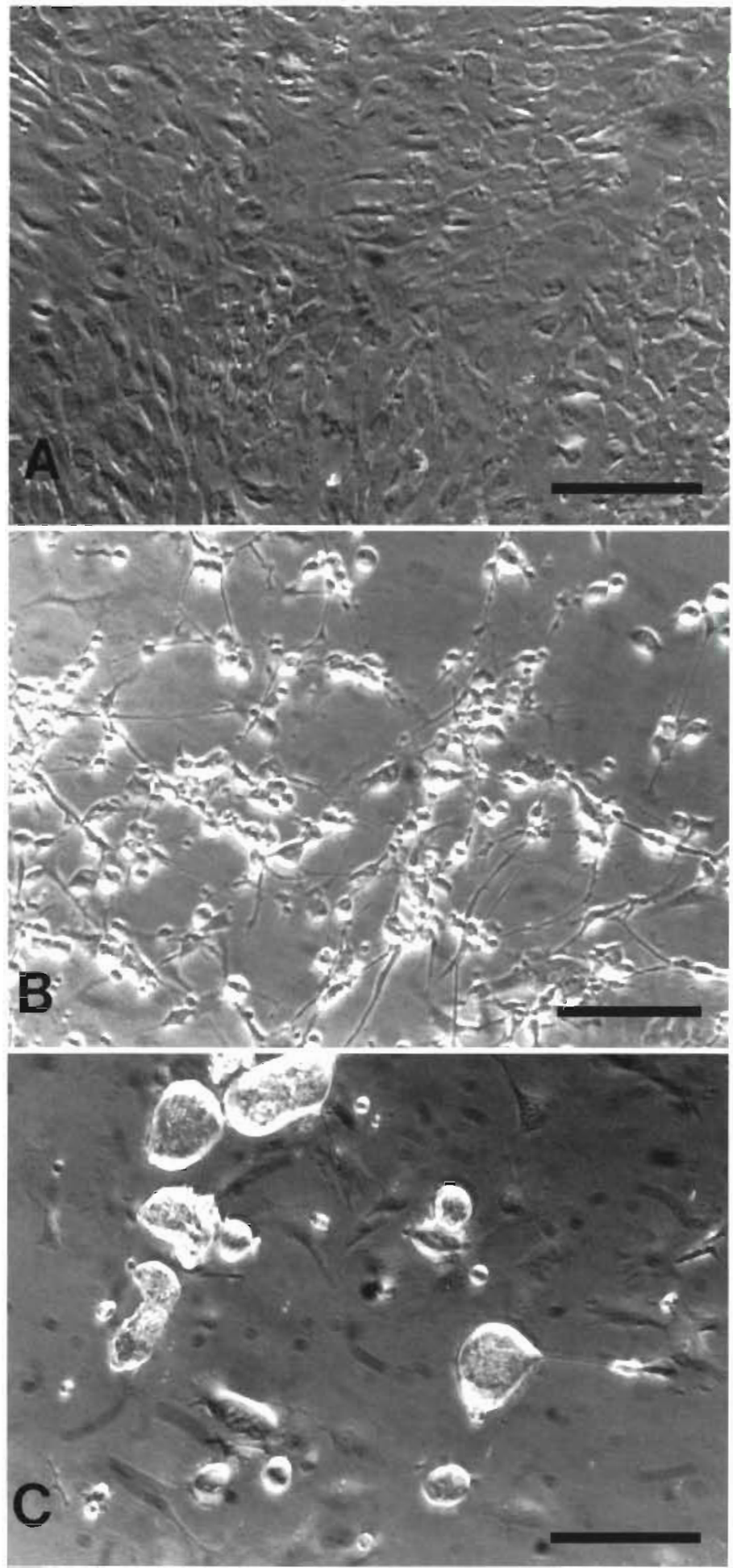

Fig. 1. Acipenser transmontanus. Cytopathic effect of WSHV-1 and WSHV-2a in white sturgeon skin cells (WSSK-1) $3 \mathrm{~d}$ post-infection ( $\mathrm{MOI}=0.1)$ examined by phase microscopy. (A) A monolayer of uninfected skin cells prior to inoculation. (B) The WSHV-2a botryoid syncytium was composed of loosely adherent cells separated by intact unit membranes. (C) The WSHV-1 polykaryocyte was typically composed of a fused mass of swollen cells and nuclei lacking intercellular membranes. Bars $=500 \mu \mathrm{m}$ 
lines but not in the non-sturgeon cell lines. Cytopathic destruction of the monolayer was complete in all the cell lines infected with WSHV-2a but was incomplete in WSS-2 and WSLV cells infected with WSHV-1. In a second experiment ( $\mathrm{MOI}=0.05$ ), a comparison of the net amount of viral production after $14 \mathrm{~d}$ showed that

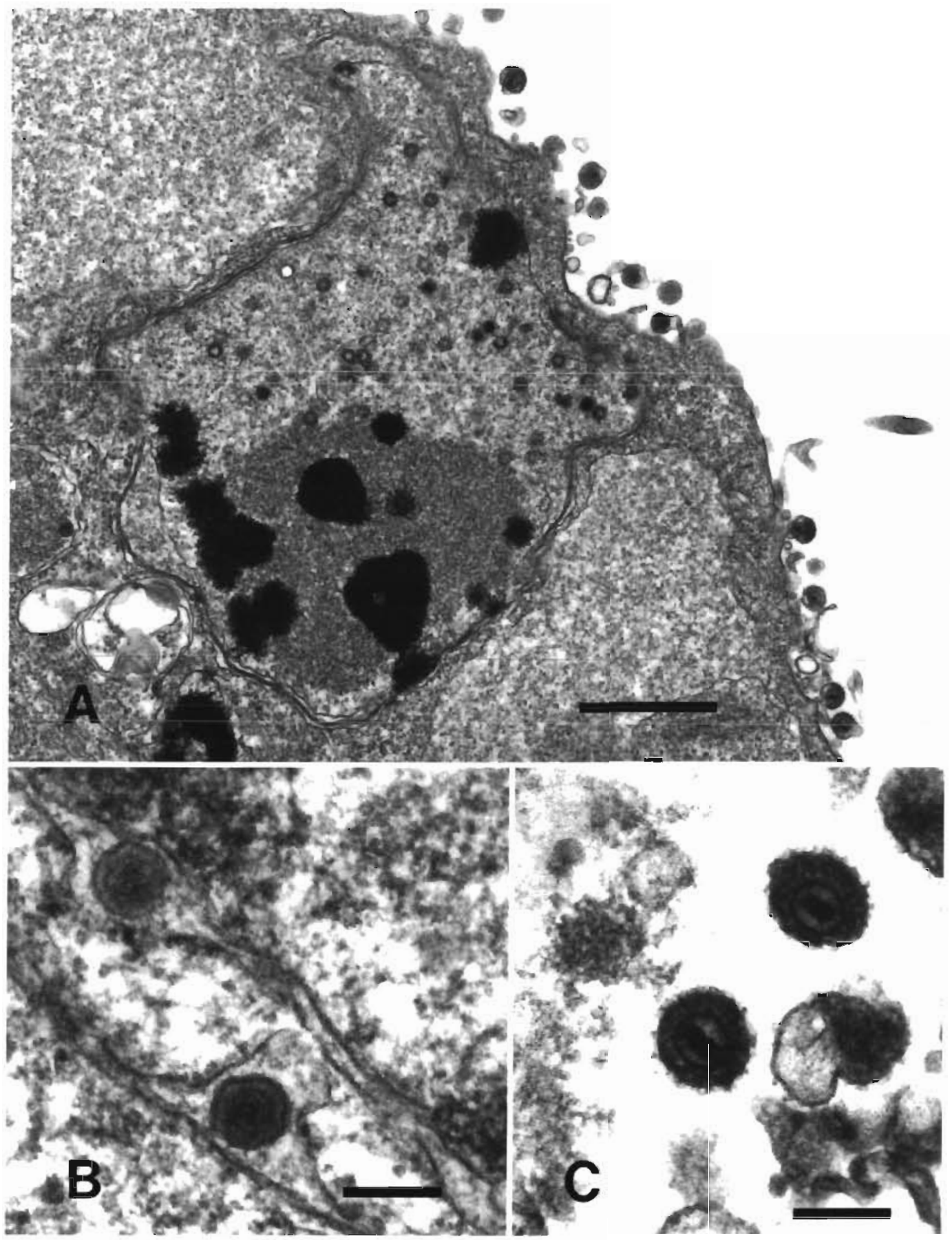

Fig. 2. Acipenser transmontanus. Sturgeon skin cells (WSSK-1) $8 \mathrm{~d}$ post-infection with WSHV-2a examined by electron microscopy. (A) Icosahedral nucleocapsids of variable density were abundant in the nuclei of the syncytium. Fully developed enveloped virions containing dense, uniform cores were released at the periphery of the cell. Bar $=1 \mu \mathrm{m}$. (B) Nuclear capsids acquiring an envelope by budding through the inner nuclear lamina. Bar $=150 \mathrm{~nm}$. (C) Mature extracellular virions displayed key properties characteristic of the Herpesviridae, including a spool-shaped high density core, low density tegument and fibrillar 


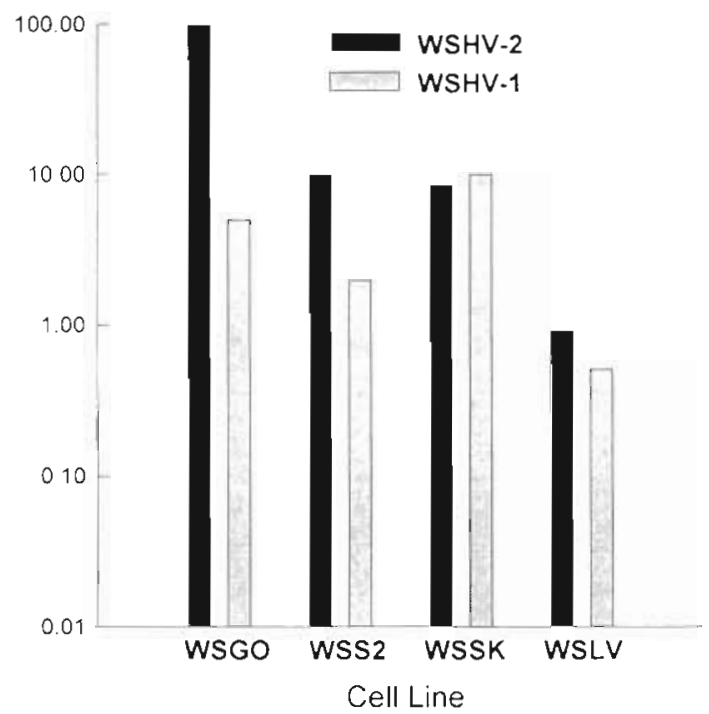

Fig. 3. Acipenser transmontanus. Growth rates of WSHV-1 and WSHV-2a in selected white sturgeon cell lines. Values are net (total less input inoculum) TCID cell ${ }^{-1}$ produced after $10 \mathrm{~d}$ at $15^{\circ} \mathrm{C}$

WSHV-2a replication was greatest in WSGO cells (98.8 $\mathrm{TCID}_{50} \mathrm{Cell}^{-1}$ ) whereas WSHV-1 replication was optimal in WSSK-1 cells (9.2 TCID 50 cell $^{-1}$ ) (Fig. 3). Only 1 sturgeon cell line, WSLV, did not produce significant amounts of either virus although partial CPE was observed.

\section{Experimental challenge}

Clinical signs became apparent in Groups A and B between 8 and $10 \mathrm{~d}$ post-challenge when fish exhibited lethargy and an erratic swimming behavior. Within a few days of these signs infected fish developed discrete, spherical to elliptical, raised hypochromatic lesions on the head and pectoral fins which were often covered with a heavy layer of mucous. Many moribund and freshly dead fish displayed hyperemia of the ventral rostrum, ventral scutes and perioral/perianal tissues. Other than occasional ascites, there were few consistent or remarkable internal signs. Unexposed controls ( $n=15$ ) showed no signs of infection nor did survivors from exposed Group C ( $\mathrm{n}=$ 9) at $70 \mathrm{~d}$ post-challenge when the study was terminated.

Dead fish first appeared in Group A (high dose) on Day 15 and in Group B (intermediate dose) on Day 16 and total cumulative mortality after $6 \mathrm{wk}$ was $78 \%$ $(7 / 9)$ and $80 \%$ (8/10), respectively (Fig. 4). No mortality $(0 / 10)$ occurred in Group C (low dose) and a total of 2 dead fish were collected from the control groups due to accidental injury. Most mortality occurred in Group A within the first $22 \mathrm{~d}(71 \%)$ whereas the majority of deaths in Group B (63\%) occurred later, between 23 and $29 \mathrm{~d}$ post-challenge.

\section{Virus recovery and titration}

Cytopathic effect, consistent with that observed in previous titrations of WSHV-2, occurring in 1 or more of the lowest dilutions from tissue homogenates was considered a 'positive' virus recovery (Table 1). The frequency of positive samples was usually greater than the number of titrated samples because in some instances the virus concentration fell below that required to establish a $\mathrm{TCID}_{50}$ (detection limit $=10^{32}$ TCID $\left._{50} \mathrm{~g}^{-1}\right)$. Virus was recovered from $63 \%(63 / 100)$ of all tissues examined (38/51 in Group $A$ and 25/49 in Group B). The highest frequency of recovery in any tissue group was from barbels (89\%). A relatively high rate of recovery was also obtained from siphon/operculum (77\%), pectoral fin (77\%), gill (75\%) and esophagus ( $69 \%$ ). In Group C, a total of $83 \%$ (25 of 30 ) of the tissues sampled from 6 survivors at $70 \mathrm{~d}$ post-challenge were positive for virus in gill, esophagus, liver, spleen and kidney. A random sampling of 45 tissues from sham-challenged controls at $70 \mathrm{~d}$ post-challenge revealed no detectable virus in the fins, siphon/operculum, gill, esophagus, heart or spleen.

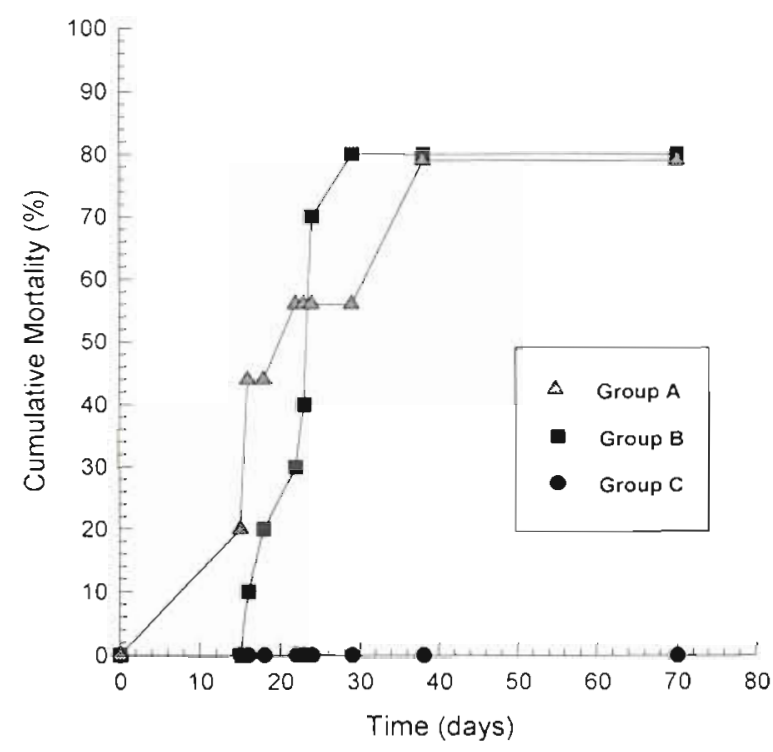

Fig. 4. Acipenser transmontanus. Cumulative mortality among juvenile white sturgeon following bath exposure to WSHV-2a at $17^{\circ} \mathrm{C}$. Exposure level $\left(\mathrm{TCID}_{50} \mathrm{ml}^{-1}\right)$ for $\mathrm{A}=10^{5}$ ! $\mathrm{B}=10^{4}$ and $\mathrm{C}=10^{3.1}$ There was no mortality in 3 control groups exposed to equivalent dilutions of tissue culture medium 
subadults (N-Sick) with skin lesions exhibited mean anti-WSHV-2b neutralizing titers of 1:80, with a maximum of 1:320. The sera from convalescing, asymptomatic fish ( $\mathrm{N}$-Convalescent) from this cohort had a mean titer of $1: 120$ and the highest titer reached 1:640

In a trial to determine antigenic relatedness between WSHV-1 and WSHV-2a and $b$, the $\mathrm{ND}_{50}$ of sera from the 2 highest reacting fish from the hyperimmunized group (E-WSHV-2) and the naturally infected subadult (N-Convalescent) were used in a TCID $_{50}$ reduction test. The titers of these sera against WSHV-2 were 1:155 and $1: 367$, respectively, while no antiviral activity was demonstrated against WSHV-1 at the lowest serum dilution of $1: 20$. In the same test there were no differences detected between the WSHV-2a and $\mathrm{b}$ isolates

\section{DISCUSSION}

The incidence and prevalence of white sturgeon viruses have been viewed with increasing concern (PSMFC 1992). Two serious viral pathogens, designated white sturgeon iridovirus (WSIV) and the first herpesvirus isolate (WSHV-1), have previously been reported in cultured white sturgeon in California (Hedrick et al. $1990,1991,1992)$. In addition, WSIV has been identified histologically in captive and feral populations in the Pacific Northwest (Holt et al. 1992, LaPatra et al. 1992, 1994). In the present study we describe a third pathogenic virus, WSHV-2, isolated for the first time from captive white sturgeon broodstock. Experimental and field data suggest that this new isolate may

Fig. 6. Acipenser transmontanus. Microscopic lesions of juvenile sturgeon exposed to WSHV2a via bath immersion (Group B) (Hematoxylin \& Eosin). (A) Severe hyperplasia and clubbing of the gill secondary lamellar epithelium. $\mathrm{Bar}=$ $100 \mu \mathrm{m}$. (B) Hyperplastic focus of the oropharyngeal epithelium (hard palate) with apparent spongiosis, sloughing of the superficial mucosa and random, individual necrotic cells. Bar = $50 \mu \mathrm{m}$. (C) Higher magnification of the previous lesion, showing prominent karyomegaly, hypochromatism, chromatin margination and cytoplasmic vacuolization. $\mathrm{Bar}=20 \mu \mathrm{m}$
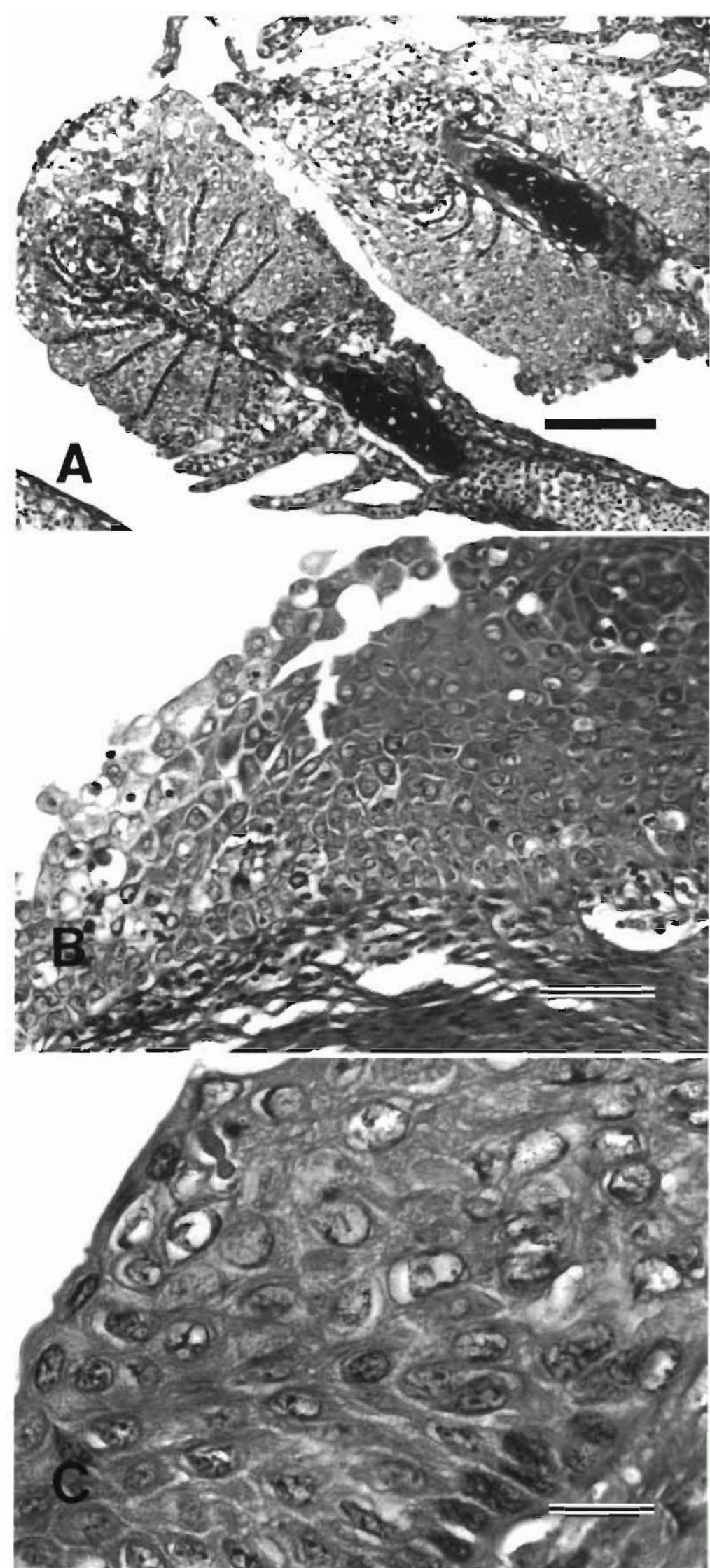
play an important role in chronic, recurrent skin diseases and related mortality in farm-reared juveniles and subadults.

The morphological properties of WSHV-2 clearly support its inclusion in the family Herpesviridae. Intranuclear assembly, perinuclear envelopment and syncytium-inducing CPE are features of WSHV-2 common to other known herpesviruses (Iida et al. 1991, Nii 1992). Additional ultrastructural characteristics include icosadeltahedral capsids measuring 100 to $110 \mathrm{~nm}$, a tegument and fibrillar nucleoprotein spool, a bilayer envelope with surface projections and an enveloped virion diameter of 100 to $200 \mathrm{~nm}$ (Roizman 1992). WSHV-2 nucleocapsid assembly and maturation were observed in the nucleus (Fig. 2A). Viral nucleocapsids were composed of a solid high-density spoollike core enclosed by a hexagonal shell. Capsid envelopment by budding through the inner nuclear membrane was also directly observed (Fig. 2B). Mature enveloped virions displaying additional distinctive morphological properties were released from the cell by a process described as reverse phagocytosis (Nii 1992) (Fig. 2C).

Although sharing certain morphological and biological properties, WSHV-2 is clearly different than WSHV-1, the only other herpesvirus known from sturgeon (Hedrick et al. 1992). The broad similarities described here include virion morphology, syncytiuminducing cytopathic effect, restricted host cell range and epitheliotropism. The CPE of WSHV-2, however, was remarkable in a number of important aspects which distinguished it from the 2 other known sturgeon viruses, WSIV or WSHV-1 (Hedrick et al. 1990, 1992). WSHV-1 induced a globoid, giant cell syncytium and was not plaque forming (Fig. 1C), whereas the WSHV-2 syncytium was botryoid and less distinct (Fig. 1B) and, under semi-solid overlays, formed plaques. Growth experiments using 4 sturgeon cell lines demonstrated preferential growth by WSHV-1 in skin-derived cells and by WSHV-2 in gonad-derived cells. Finally, in a serological comparison of WSHV-1 and WSHV-2, the sera from selected fish displaying anti-WSHV-2 titers $\left(\mathrm{ND}_{50}\right.$ ) between $10^{22}$ and $10^{2.6}$ failed to neutralize WSHV-1 even at the lowest dilution of 1:20. These serological findings, in combination with our other cytopathic and cytotropic studies, lend further support to the distinction between the WSHV-1 and WSHV-2 isolates.

The virulence of the WSHV-2a adult isolate to juvenile sturgeon was demonstrated in a water-borne exposure which resulted in clinical signs of disease within $10 \mathrm{~d}$ of contact with the virus. Beginning on Day 15 post exposure, examination of freshly dead fish revealed multifocal to diffuse epithelial hyperplasia that often became erosive in the cranial integument, pectoral fins and oropharyngeal cavity. Similar clinical signs consistent with an epitheliotropic virus were observed in 1993 in farm-reared subadults from which WSHV-2b was isolated. The CPE induced by the subadult isolate was indistinguishable from that of WSHV-2a

Epithelial hyperplasia has previously been reported as a common feature of epitheliotropic herpesvirus diseases from both freshwater and marine fishes (Békési et al. 1984, Hedrick \& Sano 1988, Bradley et al. 1989, Hetrick \& Hedrick 1993). The quantitative estimate of WSHV-2 concentrations in selected tissues shows a correspondingly higher level of virus replication in epithelial target tissues as compared to other tissues. In addition, the quantitative and histological evidence of WSHV-2 replication in the respiratory mucosa is another property distinguishing it from WSHV-1 (Hedrick et al. 1991) and other reported fish herpesviruses (Bradley et al. 1989, Iida et al. 1991). Investigators working with the epitheliotropic lake trout and Japanese flounder herpesviruses also reported indirect evidence of osmoregulatory failure, chiefly ascites, among moribund fish. In our studies, we observed occasional ascites and also noted unusually heavy mucus secretions which, by disrupting electrolyte, gas and metabolite exchange of the skin and respiratory epithelium, could have been an additional physiological factor contributing to mortality (Perry \& McDonald 1993)

In addition to detecting the highest concentrations of WSHV-2 in epithelial tissues, virus recovery studies revealed low to moderate amounts of virus in the nonepithelial tissues of the kidney, spleen and heart of dead fish in the high and intermediate challenge dose groups. However, the absence of observable proliferative or degenerative changes suggests a passive role for these tissues during the active stages of disease and thus stands in contrast to the severe kidney and endothelial damage inflicted by systemic herpesviruses such as CCV (Wolf \& Darlington 1971) and the salmonid herpesvirus-2 (Tanaka et al. 1992).

Following the appearance of clinical signs, mortality reached a cumulative total of $80 \%$ within $40 \mathrm{~d}$ at the high and intermediate exposure levels. These mortality rates were twice those reported in juvenile sturgeon exposed to concentrations 3 -fold greater (virus concentration $\mathrm{g}^{-1}$ ) of WSHV-I than the highest dose of WSHV2 used in our study (Hedrick et al. 1992). The greater mortality rate at relatively lower virus concentrations is a further indication that WSHV-2 may be more virulent in the natural host than WSHV-1

A plaque assay protocol for WSHV-2 was developed to quantitate amounts of virus for serological investigations. The $50 \%$ plaque reduction assay, using WSHV$2 \mathrm{a}$, detected neutralizing activity as high as $10^{2.8}$ in 
sera from fish exposed to either WSHV-2a or $2 b$, thus providing indirect evidence of antigenic homology between these strains. This preliminary analysis also revealed that fish produced serum neutralizing activity in both of the observed categones of natural WSHV-2 infections: (1) active disease associated with clinical signs and mortality (Table 2, Group N-Sick) and (2) chronic asymptomatic infections (Table 2, Group NConvalescent). Detection of WSHV-2 neutralizing activity in the serum of normal appearing adults and subadults (Groups Feral-Adult and $\mathrm{N}$-Convalescent) demonstrates the potential for serological analyses as a means to confirm prior contact with the virus and possible detection of latent carriers.

Our studies on the pathogenesis of WSHV-2 and recently acquired information from clinical and field work suggest at least 2 outcomes following exposures to the agent. The first is a silent infection characterized by the absence of clinical signs but presence of the virus (Challenge Group C). A second outcome is an acute infection stage (Challenge Groups A and B), characterized by cutaneous lesions, high rates of virus replication and morbidity. Following either the silent or acute infection, a recrudescent phase (farm Groups $\mathrm{N}$-Sick and $\mathrm{N}$-Convalescent) characterized by erosive dermal lesions (containing up to $10^{6.9} \mathrm{TCID}_{50} \mathrm{~g}^{-1}$ of virus) may occur. This phase may be exacerbated by farming practices or other stressors. These potentially cyclic phases of infection are characteristic of many herpesvirus infections where a persistent or latent state follows an acute phase (Ginsberg 1990).

Although the potential for vertical transmission of fish herpeseviruses has been demonstrated (Wise et al. 1988), there is currently no direct evidence that WSHV-2 resides in the gametes. The vertical mode of transmission, however, could explain the occurrence of WSHV-2 infections among sturgeon reared in singlepass well-water in the apparent absence of reservoir species. Equally important for both hatchery and fishery management are the natural reservoirs of infection and the prevalence of WSHV-2 in native sturgeon populations.

Acknowledgements. This paper is funded in part by the California Department of Fish and Game and by a grant from the National Sea Grant College Program, National Oceanic and Atmospheric Administration, U.S. Department of Commerce, under grant number NA36RG0537, project number R/A-89 through the California Sea Grant College, and in part by the California State Resources Agency. The views expressed herein are those of the authors and do not necessarily reflect the views of NOAA or any of its sub-agencies. The U.S. Government is authorized to reproduce and distribute for governmental purposes. The authors also thank Mr Robert Munn for electron microscopy expertise

\section{LITERATURE CITED}

Amos K (1985) Procedures for the detection of certain fish pathogens. Fish Health Section Bluebook, American Fisheries Society, Bethesda, MD

Békesi L, Kovacs-Gayer E, Ratz F, Turkovics O (1984) Skin infection of the sheatfish (Siluris glanis L.) caused by a herpes virus. Symp Biol Hung 23:25-30

Bowser P. Plumb J (1980) Fish cell lines: establishment of a cell line from ovaries of channel catfish. In Vitro 16:365-368

Bradley TM, Medina DJ, Chang PW, McClain J (1989) Epizootic epitheliotropic disease of lake trout (Salvelinus namaycush): history and viral etiology. Dis aquat Org 7 : $195-201$

Carey T (1983) Regional control of communicable diseases of fish In: Meyer F, Warren J, Carey $T$ (eds) A guide to the integrated fish health management in the Great Lakes Basin. Special Publication 83-2, Great Lakes Fishery Commission, Ann Arbor, MI

Conte FS, Doroshov SI, Lutes PB (1988) Hatchery manual for the white sturgeon Acipenser transmontanus with application to other North American Acipenseridae. Publication 3322, Cooperative Extension, Division of Agriculture and Natural Resources, University of California, Davis

Doroshov S (1985) Biology and culture of sturgeon, Acipenseriformes. In: Muir J, Roberts R (eds) Recent advances in aquaculture 2:251-275

Fijan $N$ and 7 coauthors (1983) Some properties of the epithelioma papillosum cyprini (EPC) line from common carp Cyprinus carpio. Ann Virologie (Paris) 134:207-220

Gravell M, Malsberger R (1965) A permanent cell line from the fathead minnow (Pimephales promelas). Ann NY Acad Sci 126:555-565

Ginsberg H (1990) The herpesviruses. In: Davis B et al (eds) Microbiology, 4th edn. JB Lippincott Co, Philadelphia, PA

Goede R (1986) Management considerations in the stocking of diseased or carrier fish. In: Stroud P (ed) Fish culture and fisheries management. American Fisheries Society, Bethesda, MD

Hedrick RP, Sano T (1988) Herpesviruses of fishes. In: Ahne W. Kurstak E (eds) Viruses of lower vertebrates. SpringerVerlag, New York, p 161-170

Hedrick RP, Groff JM, McDowell TS, Wingfield WH (1990) An iridovirus from the integument of white sturgeon. Dis aquat Org 8:39-44

Hedrick RP, McDowell TS, Groff JM, Yun S, Wingfield WH (1991a) Isolation of an epitheliotropic herpesvirus from white sturgeon Acipenser transmontanus. Dis aquat Org 11:49-56

Hedrick RP, McDowell TS, Rosemark R, Aronstein D, Lannan CN (1991b) Two cell lines from white sturgeon. Trans Am Fish Soc 120:528-534

Hempel E (1993) Constraints and possibilities for developing aquaculture. Aquaculture International 1:2-19

Hetrick. FM, Hedrick RP (1993) New viruses described in finfish from 1988-1992. A Rev Fish Dis 3:187-207

Holt R, Groff J, Kreps T, Hedrick R (1992) Iridovirus in cultured white sturgeon (Acipenser transmontanus) from the Lower Columbia River. Fish Health Newsl 20 (3):4

Iida Y, Nakai T, Sorimachi M, Masumura K (1991) Histopathology of a herpesvirus infection in larvae of Japanese flounder Paralichthys olivaceus. Dis aquat Org 10:59-63

Lannan C, Winton J, Fryer J (1984) Fish cell lines: establishment and characterization of nine cell lines from salmonids. In Vitro 20:671--676

LaPatra S and 7 coauthors (1992) Occurrence of white sturgeon iridovirus (WSIV) infection in Idaho Snake River 
white sturgeon. Fish Health Newsl 20(2):1-3

LaPatra $S$ and 6 coauthors (1994) Occurrence of white sturgeon rridovirus infections among white sturgeon in the Pacific Northwest. Aquaculture 126:201-210

Nii S (1992) Electron microscopic study on the development of herpesviruses. J Electron Microsc 41:4.14-423

Perry S, McDonald G (1993) Gas exchange. In: Evans D (ed) The physiology of fishes. CRC Press, Inc, Boca Raton, p 251-278

PSMFC (Pacific States Marine Fisheries Commission) (1992) White sturgeon management framework plan. Prepared by the White Sturgeon Planning Committee, PSMFC, Portland, OR

Reed LJ, Muench H (1938) A simple method of estimating

Editorial responsibility: Managing Editor fifty percent endpoints. Am J Hygiene 27:493-497

Roizman B (1992) The Herpesviridae. In: Francki et al (eds) Classification and nomenclature of viruses. Arch Virol (Suppl) 2:103-110

Tanaka M, Yoshimizu M, Kimura T (1992) Herpesvirus infection of salmonid fish. In: Kimura $T$ (ed) Salmonid diseases. Hokkaido University Press, Sapporo, p 111-117

Wise JA, Harrell SF, Busch RL, Boyle JA (1988) Vertical transmission of channel catfish virus. Am $\mathrm{J}$ Vet Res 49: 1506-1.509

Wolf K, Darlington W (1971) Channel catfish virus: a new herpesvirus of 1.ctalurid fish. J Virol 8:525:533

Wolf K, Quimby M (1962) Established eurythermic line of fish cells in vitro. Science 135:1065-1066

Manuscript first received: October 26, 1994

Revised version accepted: March 20, 1995 